\title{
IMPLEMENTASI PROGRAM HAFALAN AL-QUR'AN DI SMP ISLAM MBAH BOLONG JOMBANG
}

\author{
Khoirun Nisa' \\ UNWAHA Tambakberas Jombang \\ neesaalkhoirot@unwaha.ac.id \\ Chusnul Chotimah \\ UNWAHA Tambakberas Jombang \\ chusnulchotimah@unwaha.ac.id
}

\begin{abstract}
: this school is classified as a private high school which has excellent programs as local content by implementing the Al-Qur'an memorization program. Each class must be able to achieve the memorization that has been determined by the school as a rote target. This study aims to (1) Know the implementation of local recitation program for memorizing Al-Qur'an (2) Knowing how the implementation and assessment of the Al-Qur'an memorization program in the school. The results of this study indicate that SMP Islamic Mbah Bolong Jombang has implemented a memorization program of the Al-Qur'an as a froom of implemtation of the local content curriculum aas well as the provision of the school founders. Learning outcomes in the froom of aral and written examination.
\end{abstract}

Keyword: Al-Qur'an memotization Program, Islamic Junior high school Student 


\section{PENDAHULUAN}

Terkait dengan pendidikan sekolah adalah salah satu tempat formal untuk melaksanakan kegiatan atau proses pendidikan. Sekolah terbagi dalam dua kategori yaitu sekolah negeri dan sekolah wasta. Sekolah negeri adalah sekolah yang mendapat bantuan dana dari pemerintah, sedangkan sekolah swasta adalah sekolah yang dibangun dan didirikan oleh suatu lembaga atau yayasan baik itu lembaga keagamaan maupun lembaga non keagamaan.

Sekolah SMP Islam Mbah Bolong ini tergolong sekolah swasta yang mempunyai program unggulan muatan lokal yaitu menerapkan Program Hafalan Al-Qur'an. Sekolah SMP ini mengisi tambahan jam sekolah dengan hafalan Al-Qur'an. Setiap kelas harus mampu mencapai hafalan yang ditentukan oleh sekolah. Kelas 7 hafalan juz ke 30 (QS. An Naba' s.d QS. An-Naas), Kelas 8 menghafal juz 29 penuh (QS. Al-Mulk s.d QS. Al-Mursalat) dan Al-Baqoroh, Kelas 9 menghafal Yasiin, ArRahman, Al-Mulk, Al-Waqi'ah, Al-KAhfi, As-Sajdah, Ad-Dukhan, AlHasyr, Muhammad, Ibrahim, Luqman, Yusuf, Maryam.

Secara operasional sudah menjadi tugas dan kewajiban bagi umat Islam agar selalu menjaga dan memelihara Al-Qur'an yaitu dengan cara menghafalnya. Namun keadaan di zaman modern ini, masih sedikit sekali orang Islam yang mau menghafal Al-Qur'an. Menghafal Al-Qur'an merupakan amal ibadah oleh karenanya pasti akan mengalami rintangan dan hambatan baik dari dalam dan dari luar, apalagi zaman sekarang dimana arus globalisasi dan modernisasi tidak bisa dihindari. Oleh karenanya sangat diperlukan metode menghafal secara sistematis untuk menunjang proses menghafal peserta didik.

Target hafalan yang ada di SMP Islam Mbah Bolong wajib dipenuhi oleh semua peserta didik. Apabila terdapat siswa baru dari sekolah lain dan belum memenuhi target hafalan, maka akan memberikan tambahan materi secara khusus. Semua siswa wajib untuk selalu melatih, membaca, dan menghafalkan secara berulang-ulang dan terus menerus target hafalan yang sudah terpenuhi termasuk yang dihafalkan pada tahun kelas sebelumnya. ${ }^{1}$

Melalui target-target yang telah ditentukan oleh pihak sekolah terhadap muatan lokal yaitu hafalan Al-Qur'an. Setiap guru pastinya memiliki metode atau cara tersendiri supaya siswanya bisa mencapai target yang telah ditentukan. Salah satu strategi yang dipakai oleh setiap guru dalam menyuruh siswanya untuk hafalan Al-Qur'an adalah memantau peserta didik lewat wali muridnya atau dengan perantara orang tua peserta didik.

\footnotetext{
${ }^{1}$ Hasil wawancara dengan staf Tata usaha SMP Islam "Mbah Bolong” Jombang
} 
Dengan penjelasan diatas. Peneliti akan membahas bagaimana penerapan program hafalan Al-Qur'an yang dierapkan di SMP Islam Mbah Bolong Jombang yang meliputi: Perencanaan, Pelaksanaan, serta Penilaian dari implementasi program hafalan Al-Qur'an di SMP Islam Mbah Bolong.

Dalam pelaksanaan program hafalan Al-Qur'an di SMP Islam Mbah Bolong Jombang pendekatan yang peneliti gunakan dalam penelitian ini adalah pendekatan kualitatif deskriptif. Metode penelitian kualitatif ini sering disebut "metode penelitian naturalistik" karena penelitian dilaksanakan pada situasi yang alamiah. ${ }^{2}$ Dalam penelitian Kualitatif terdapat 3 hal yang perlu diuraikan yaitu, karakteristik pelaku, kegiatan atau kejadian-kejadian yang terjadi selama penelitian, dan keadaan lingkungan atau karakteristik tempat penelitian berlangsung. ${ }^{3}$

Teknik pengumpulan data adalah cara yang dipakai untuk mengumpulkan informasi atau fakta-fakta lapangan. ${ }^{4}$ Adapun pada penelitian ini peneliti menggunakan 3 macam teknik pengumpulan data, yaitu:

\section{Observasi}

Observasi ialah pengamatan dan pencatatan yang sistematis terhadap gejala-gejala yang diteliti. ${ }^{5}$ Menurut Andi Prastowo observasi merupakan kemampuan seseorang untuk menggunakan pengamatan melalui hasil kerja indra dengan dibantu panca indra lain. Nasution dalam Sugiyono mengatakan bahwa Observasi adalah dasar sebuah ilmu pengetahuan. Dalam hal ini peneliti mengamati implementasi metode hafalan yang dilakukan oleh ustadz/ustadzah kepada para siswa di SMP Islam Mbah Bolong.

\section{Wawancara}

Wawancara adalah pertemuan yang dilakukan oleh dua orang untuk bertukar informasi dan ide melalui tanya jawab sehingga bisa membangun makna dalam suatu topik tertentu

\section{Dokumentasi}

Pengumpulan dan pengambilan data yang diperoleh melalui dokumen-dokumen adalah teknik pengumpulan data dengan dokumentasi. Dokumen bisa berbentuk tulisan, gambar, atau karya-karya monumental dari seseorang. Dokumentasi merupakan pelengkap dari penggunaan metode observasi dna wawancara dalam penelitian.

\footnotetext{
2 Andi Prastowo, Metode Penenlitian Kualitatif dalam Perspektif Rancangan Penelitian, (Jogjakarta, Ar-Ruzz Media, 2011), 22

${ }^{3}$ Husaini Usman dan Purnama Setiadi Akbar, Metodologi Penelitian Sosial, (Jakarta: Bumi Aksara, 2009), 130

${ }^{4}$ Andi Prastowo, Metode Penelitian....., 208

${ }^{5}$ Ibid, 52
} 
Dengan adanya penelitian ini diharapkan bisa meningkatkan program unggulan berupa program hafalan Al-Qur'an di SMP Islam Mbah Bolong serta dapat dijadikan pemahaman dini untuk tetap mencintai Al-Qur'an bagi siswa itu sendiri dan dapat menjadi bekal setelah keluar dari SMP Islam Mbah Bolong.

\section{IMPLEMENTASI}

Implementasi menurut kamus lengkap Bahasa Indonesia yaitu "penerapan atau pelaksanaan". ${ }^{6}$ Menurut Nana Sudjana, implementasi dapat diartikan sebagai upaya pimpinan untuk memotivasi seseorang yang dipimpin dengan menumbuhkan dorongan dalam dirinya untuk melakukan tugas atau kegiatan yang diberikan sesuai dengan rencana.dalam rangka mencapai tujuan. ${ }^{7}$ Jadi implementasi atau penerapan itu merupakan suatu kegiatn yang terencana untuk mencapai tujuan suatu kegiatan.

Dari penjelasan diatas dapat disimpulkan bahwa implementasi adalah pelaksanaan atau penerapan sebuah kegiatan yang memerlukan keterampilan dan motivasi untuk mewujudkan tujuan yang diinginkan dan ketika mencapai tujuan tersebut diperlukan adanya suatu rencana yang kemudian rencana tersebut dilaksanakan dalam mekanisme tertentu.

\section{PENGERTIAN PROGRAM}

Menurut kamus umum Bahasa Indonesia program adalah "rencana atau rancangan mengenai suatu serta usaha-usaha yang akan dijalankan. ${ }^{8}$ Menurut Suharsimi dan Cepi, program dapat didefinisikan sebagai "suatu unit atau kesatuan kegiatan yang merupakan perwujudan dari suatu kebijakan atau aturan yang berlangsung dalam proses berkesinambungan dan terjadi dalam suatu organisasi yang melibatkan sekelompok orang".

Berdasarkan pengertian tersebut dapat disimpulkan bahwa ada beberapa unsur pokok untuk dapat dikategorikan sebagai program:

Pertama: Kegiatan tersebut sudah direncanakan dan dirancang dengan seksama

Kedua: Kegiatan itu berlangsung secara berkelanjutan dari satu kegiatan ke kegiatan lain atau adanya keterkaitan antara kegiatan sebelumnya

\footnotetext{
${ }^{6}$ Indrawan W.S. Kamus Lengkap Bahasa Indonesia, (Jombang: Lintas Media), 2000, 231

${ }^{7}$ Nana sudjana, Dasar-dasar Proses Belajar Mengajar (Bandung: Sinar Baru, 2009)

8 W.J.S Poerdarminta, Kamus umum Bahasa Indonesia, (Jakarta: Balai Pustaka, 1982), 965

9 Suharsimi Arikunto dan Ceci safrudin, Evaluasi Program Pendidikan (Pedoman Teoritis Praktis bagi Mahasiswa dan Praktisi Pendidikan (Jakarta: Bumi Aksara, 2010) cet ke-2 , 4
} 
Ketiga: Kegiatan harus berlangsung dalam sebuah organisasi, baik itu formal atau nonformal.

Keempat: Kegiatan tersebut melibatkan banyak orang dalam pelaksanaannya.

\section{IMPLEMENTASI PROGRAM HAFALAN AL-QUR'AN}

Implementsi Program Hafalan Al-Qur'an merupakan penerapan suatu kegiatan dalam menghafal Al-Qur'an. Menurut Khalid, program menghafal Al-Qur'an adalah menghafal Al-Qur'an dengan mutqin (hafalan yang kuat) terhadap lafadz-lafadz Al-Qur'an dan menghafal maknanya dengan kuat yang memudahkan untuk menghadirkannya setiap menghadapi berbagai masalah kehidupan, Al-Qur'an senantiasa selalu ada dan hidup di dalam hati sepanjang waktu kapanpun dan dimanapun sehingga memudahkan untuk menerapkan dan mengamalkannya. ${ }^{10}$

Adapun program tahfidz Al-Qur'an merupakan suatu rencana dan pengajaran tentang kegiatan menghafalkan semua surat dan ayat yang sudah ditentukan, untuk melafalkan dan mengucapkannya kembali secara lisan pada semua surat dan ayat tersebut sebagai aplikasi dalam menghafal Al-Qur'an. ${ }^{11}$

Jadi implementasi program hafalan Al-Qur'an jika dilaksanakan di sekolah adalah pelaksanaan rencana kegiatan menghafalkan Al-Qur'an untuk seluruh siswa sesuai kebijakan atau aturan yang sudah ditentukan. Setelah menghafalkan seluruh siswa diharapkan menyetorkan hafalannya kepada guru pembimbing tahfidz atau guru yang telah ditentukan oleh sekolah. Dalam pelaksanaan program tersebut disesuaikan dengan kebutuhan dan kebijakan dari tiap masing-masing sekolah sendiri.

\section{Landasan Pelaksanaan Program Hafalan Al-Qur'an}

Surat al-Ankabut (29) ayat 48-49 tentang keutamaan dari menghafal AlQur'an.

'Dan kamu tidak pernah membaca sebelumnya (Al-Qur'an) sesuatu Kitabpun dan kamu tidak (pernah) menulis suatu Kitab dengan tangan kananmu: andaikata (kamu pernah membaca dan menulis), benar-benar ragulah orang yang mengingkari(mu). Sebenarnya, AlQur'an itu adalah ayat-ayat yang nyata di dalam dada orang-orang

\footnotetext{
${ }^{10}$ Khalid bin Abdul Karim Al-Lahim, Metode Mtakhir Cara Cepat Menghafal (Bandung: Rosdakarya, 2011), 36

${ }^{11}$ Kementrian Agama Provinsi DKI Jakarta, Kurikulum Muatan Lokal HAfalan Al-Qur'an Madrasah Tsanawiyah (DKI Jakarta, 2013), 3
} 
yang diberi ilmu. Dan tidak ada yang mengingkari ayat-ayat Kami kecuali orang-orang yang zalim" 12

Surat Al-Qiyamah (75) 17-18 tentang perintah membaca Al-Qur'an "Sesunggubnya atas tanggungan Kamilab mengumpulkannya (di dadamu) dan (membuatmu pandai) membacanya. Apabila Kami telah selesai membacakannya maka ikutilah bacaannya ini"'13

\section{Tujuan Program Tahfidz (hafalan) Al-Qur'an}

Tujuan adanya pelaksanaan program tahfiz (menghafal) Al-Qur'an di sekolah adalah untuk menyiapkan peserta didik di sekolah tersebut agar mampu untuk membaca, menghafalkan, mempelajari, mengamalkan dan menjunjung tinggi nilai-nilai yang terkandung dalam Al-Qur'an.

Menurut Ahmad Lutfi tujuan program menghafal Al-Qur'an di sekolah antara lain:

1. Peserta didik bisa memahami dan mengetahui arti pentingnya kemampuan dalam menghafal Al-Qur'an

2. Peserta didik terampil menghafal ayat-ayat atau bacaan dari surat-surat yang menjadi materi pelajaran

3. Peserta didik mampu untuk membiasakan menghafal Al-Qur'an agar dalam berbagai kesempatan peserta didik tersebut selalu melafadzkan ayat-ayat Al-Qur'an dalam kegiatan sehari-hari. ${ }^{14}$

\section{Materi Dalam Program Menghafal Al-Qur'an}

Sistem ingatan manusia sebenarnya dibagi menjadi 3 bagian yaitu: pertama, sensori memori (sensory memory): kedua, ingatan jangka pendek (short term memory); dan ketiga; ingatan jangka panjang (long term memory). Sensor memori mencatat informasi atau stimulus yang masuk melalui salah satu atau kombinasi panca indera, yaitu secara visual melalui mata, pendengaran melalui telinga, bau melalui hidung, rasa melalui lidah dan rabaan melalui kulit. Bila informasi atau stimulus tersebut tidak diperhatikan akan langsung terlupakan, namun bila diperhatikan maka informasi tersebut ditransfer ke sistem ingatan jangka pendek. Sistem ingatan jangka pendek akhirnya menyimpan informasi itu selama 30 detik, dan cuma sekitar tujuh bongkahan informasi (chunks) bisa dipelihara dan disimpan dalam system jangka pendek setiap saat. Setelah berada di sistem ingatan jangka pendek, informasi tersebut dapat

\footnotetext{
12 Al-Qur'an dan terjemahannya

${ }_{13}$ Al-Qur'an dan terjemahannya

${ }^{14}$ Ahmad Lutfi, Pembelajaran Al-Qur'an dan Hadits (Jakarta: Direktorat Pendidikan Islam, 2009), 168-169
} 
ditransfer lagi melalui proses latihan atau pengulangan ke dalam sistem ingatan jangka panjang untuk disimpan, atau bisa juga informasi tersebut akan hilang bahkan terlupakan jika tergantikan oleh tambahan beberapa informasi yang baru lagi. ${ }^{15}$

Menurut Atkison yang dikutip oleh Sa'dullah mengatakan proses dalam menghafal itu harus melewati tiga proses yaitu: ${ }^{16}$

Encoding (memasukkan informasi ke dalam ingatan). Encoding adalah suatu proses memasukkan data-data informasi ke dalam ingatan. Proses ini harus menggunakan dua alat indera manusia, yaitu penglihatan dan pendengaran.

Storage (Penyimpanan), storage adalah penyimpanan informasi yang masuk di dalam gudang memori. Gudang memori terletak di dalam memori panjang (Long term Memory). Semua informasi yang dimasukkan dan disimpan di dalam gudang memori itu tidak akan pernah hilang. Sebenarnya yang dinamakan dengan lupa itu hanya saja tidak berhasil dalam menemukan kembali informasi tersebut di dalam gudang memori.

Retrieval (Pengungkapan kembali). Retrieval adalah pengungkapan kembali informasi yang sudah disimpan di dalam memori kadangkala ikut serta merta dan kadangkala dibutuhkan pancingan. Jika usaha untuk mengingat kembali gagal atau tidak berhasil padahal dengan pancingan biasanya orang menyebutnya dengan sebutan lupa. Lupa itu biasanya ketidakberhasilan kita dalam menemukan informasi dalam gudang memori padahal ia pun masih tetap ada disana.

Materi dalam program menghafal Al-Qur'an di sekolah pastinya sudah ditentukan dengan kebutuhan dan kebijakan dari sekolah adapun materi tersebut untuk tingkatan SMP kelas 7, 8 dan 9 yaitu:

a. Materi hafalan untuk tingkat Tsanawiyah atau menengah kelas 7 adalah Al-Qur'an juz 30 mulai dari An-Naba - An-Naas.

b. Materi hafalan untuk tingkat Tsanawiyah atau menengah kelas 8 adalah Al-Baqoroh

c. Materi hafalan untuk tingkat Tsanawiyah atau menengah kelas 9 adalah juz 29 mulai dari Al-Mulk-Al-Mursalah.

\footnotetext{
15 Ahamd Lutfi, Pembelajaran Al-Qur'an dan Hadits.., 167

${ }^{16}$ Imam An-Nawawi, Adab dan Tata Cara Menjaga Al-Qur'an, Jakarta: Pustaka Amani, 2001), 49.50
} 
Tabel 1.1

Materi Hafalan sesuai kelasnya

\begin{tabular}{|l|c|}
\hline \multicolumn{1}{|c|}{ Materi Hafalan } & Tingkatan kelas \\
\hline Juz 30 (An-Naba - An-Naas) & 7 \\
\hline Juz 1 (Al-Baqoroh) & 8 \\
\hline Juz 29 (Al-Mulk - Al-Mursalah) & 9 \\
\hline
\end{tabular}

\section{Metode dalam Program Hafalan Al-Qur'an}

Metode bi al-Nazhar

Metode bi al-nazhar, yaitu membaca cermat ayat Al-Qur'an yang akan dihafal dengan berulang-ulang. Metode ini merupakan salah satu metode dalam mempercepat hafalan Al-Qur'an karena sering dibaca terus berulang-ulang sebelum menghafalkannya. Tujuannya agar lebih mengetahui dulu ayat-ayat yang akan dihafalkannya sehingga tidak terdengar asing lagi dengan bacaan atau ayat-ayat tersebut. Semakin sering untuk dibaca maka akan sering ingat dalam menghafal bagi si penghafal Al-Qur'an. ${ }^{17}$

\section{Metode Kitabah}

Metode Kitabah yaitu metode dimana orang yang hafidz atau penghafal Al-Qur'an sebelum menghafalkan mereka menulis dulu ayatayat tersebut dalam buku khusus yang sudah disiapkan. Setelah ditulis kemudian ayat-ayat tersebut dibacanya sehingga bisa menjadi lancar dan benar bacaannya kemudian dihafalkan. dengan metode kitabah maka akan lebih mudah dalam merekam hafalan di ingatannya karena dengan menulis ayat tersebut secara berulang-ulang dan terus menerus tentu si penghafal dapat dengan mudah memperhatikan dan menghafalkan bacaan dalam ayat-ayat Al-Qur'an di dalam hati.

\section{Metode Sima'i}

Metode Sima'i adalah metode hafalan dengan cara mendengarkan dan menyimak suatu bacaan dalam ayat Al-Qur'an untuk dihafalkan. Metode ini bisa dilakukan dengan dua cara yaitu: Satu: Mendengar langsung dari guru yang mengajarkannya, terutama bagi penghafal tunanetra atau anak-anak. Harapannya guru disuruh untuk lebih sabar dan telaten dalam membimbing dan mengarahkan para penghafal AlQur'an dalam proses menghafalkan. Dua: Merekam bacaan ayat AlQur'an dalam tape recorder atau menggunakan alat perekam pada HP (Handphone) sesuai kebutuhan dan kemampuannya. Kemudian apa yang direkam diputar dan didengar sambil menirukan bacaannya. Metode

${ }^{17}$ Wiwi, Cara Cepat Bisa Menghafal Al-Qur'an, (Yogjakarta: Kencana Media, 2008) 102 
sima'i sangat membantu sekali dalam proses menghafal Al-Qur'an jadi cara menerapkan metode sima'i yaitu dengan membuat metode teratur untuk mendengarkan bacaan ayat Al-Qur'an yang sedang dihafalkan dengan kaset atau music di handphone dari syeikh besar yang terkenal dan terpercaya akan kefasihan dalam menghafal Al-Qur'an seperti Syeikh Khusari dan Syeikh Abdul Basith untuk bacaan murottal Al-Qur'an. ${ }^{18}$

\section{Metode Talaqqi}

Metode Talaqqi yaitu metode setoran dimana para penghafal AlQur'an langsung menyetorkan hafalannya atau memperdengarkan hafalan yang baru dihafal kepada guru atau ustadz yang membimbingnya atau bisa dengan teman sebaya sehingga dengan metode talaqqi ini dapat mengetahui hasil hafalan Al-Qur'an.

Menyetorkan hafalan Al-Quran kepada guru sebenarnya sudah dilakukan pada zaman Rasullullah SAW karena pada dasarnya Al-qur'an itu diambil dengan cara talaqqi (berguru kepada ahlinya) dan metode ini sangat dianjurkan berguru kepada para ahli atau langsung dari lisan para ulama yang faham betul mengenai bacaan dan lafadz-lafadz di dalam AlQur'an.

\section{Metode Takir}

Metode Takrir ialah metode dengan mengulang- ulang hafalan dan mendengarkan hafalannya kepada guru pembimbingnya atau dengan temannya dan metode ini bisa dilakukan kapanpun dan dimanapun berada sehingga berguna untuk kelancaran dalam menghafal lafadz atau bacaan yang ada dalam ayat-ayat Al-Qur'an sehingga mengantisipasi agar hafalannya bisa kuat dan tidak gampang lupa.

\section{Metode Jama'}

Metode ini adalah dengan menghafalkan Al-Qur'an secara bersama-sama sehingga ayat-ayat yang mau dihafalkan dibaca dulu bersama-sama yang dipimpin oleh guru pembimbingnya. ${ }^{19}$

\section{Hasil Penelitian}

\section{Perencanaan Program Hafalan Al-Qur'an}

Dalam perencanaan program hafalan Al-Qur'an yang ada di SMP Islam Mbah Bolong Jombang ini ada beberapa langkah dalam menyusun

\footnotetext{
18 Yahya Abdul Fattah Az-zawawi, Revolusi Menghafal Al-Qur'an, (Surakarta: Insan Kamil, 2013), 51

19 A.W. Munawwir, Kamus Al-Munawwir Arab - Indonesia, (Surabaya: Pustaka Progressif, 1997), Cet ke 14, 279
} 
program yang akhirnya menjadi program unggulan di SMP Islam Mbah Bolong Jombang yaitu:

\section{a. Menetapkan Program}

Program hafalan Al-Qur'an di SMP Islam Mbah Bolong Jombang ditetapkan sebagai kurikulum muatan lokal karena dengan adanya program hafalan tersebut dirasa sangat bermanfaat yaitu membiasakan siswa terampil dalam menghafal dan meningkatkan kemampuan pemahaman terhadap kitab suci Al-Qur'an. Ini juga melalui proses musyawarah dengan berbagai pihak yang terlibat di dalamnya termasuk komite, kepala sekolah dan pihak yang ikut bekerjasama dalam mendirikan sekolah.

Penetapan Program hafalan Al-Qur'an di dalam SMP Islam Mbah Bolong Jombang ini sebagai ciri khas sekolah dimana telah dibebaskan bahwa sekolah dapat menentukan sendiri muatan lokal sebagai ciri khas sekolah tersebut.

Penetapan program Hafalan SMP Islam Mbah Bolong Jombang ini mengacu pada visi dan misi sekolah yang mana menginginkan agar anak didik di sekolah Islam Mbah Bolong Jombang menjadi peserta didik pejuang Islam yang tangguh. Ketangguhan yang diinginkan melalui pemahaman Al-Qur'an.

b. Bermanfaat dan mempunyai Tujuan

Manfaat dan tujuan ini sebagai acuan untuk tercapainya suatu program yang diterapkan. Adapun manfaat dan tujuan dalam penetapan program hafalan Al-Qur'an di SMP Islam Mbah Bolong Jombang antara lain: pertama, untuk menerapkan program muatan lokal sesuai keinginan sekolah. Kedua, Peserta didik yang sudah selesai study di SMP Islam Mbah Bolong diharapkan agar mampu menghafalkan sesuai target yang sudah ditentukan oleh pihak sekolah. Ketiga, Agar mampu mengenalkan kepada peserta didik bahwa dengan mempelajari Al-Qur'an itu merupakan suatu hal yang penting sekali baik di dunia maupun di akhirat kelak, Keempat, Bisa mendorong, membina dan membimbing peserta didik untuk mencintai Al-Qur'an dengan cara menghafal dan mengerti ayat-ayat yang terkandung dalam Al-Qur'an.

c. Menentukan Tangggungjawab

Penentuan tanggungjawab ini sesuai dengan bidang masingmasing. Di SMP Islam Mbah Bolong tentunya mempunyai struktur organisasi yang mana ada garis koordinat antara atasan dan juga anggota. Penanggungjawab ini ditentukan langsung oleh kepala sekolah dan kemudian membagi guru kelas untuk menjadi penanggujawab di tiap kelas masing-masing, dan ada 3 guru khusus hafalan Al-Qur'an sebagai penanggung jawab dalam proses berlangsungnya pembelajaran dalam program hafalan Al-Qur'an. 


\section{d. Penentuan Aloksi Waktu}

Alokasi waktu untuk melakukan kegiatan pembelajaran pada program hafalan al-Qur'an di SMP Islam Mbah Bolong Jombang pastinya sudah terjadwal dan tersusun.

Tabel 2.1

Jadwal Kegiatan Sekolah

\begin{tabular}{|c|c|c|}
\hline Jam & Kegiatan & Penanggungjawab \\
\hline $07.00-07.30$ & $\begin{array}{c}\text { Mengaji bersama sebelum } \\
\text { belajar di kelas }\end{array}$ & Kepala sekolah dan guru \\
\hline $07.30-09.00$ & $\begin{array}{c}\text { Belajar di kelas masing- } \\
\text { masing }\end{array}$ & Guru kelas \\
\hline $09.00-09.30$ & Istirahat + Sholat Dhuha & Kepala sekolah dan guru \\
\hline $09.30-11.15$ & $\begin{array}{c}\text { Belajar di kelas masing- } \\
\text { masing }\end{array}$ & Guru kelas \\
\hline $11.15-13.00$ & ISHOMA & $\begin{array}{c}\text { Seluruh guru dan } \\
\text { karyawan }\end{array}$ \\
\hline $13.00-14.00$ & $\begin{array}{c}\text { Menghafal surat-surat } \\
\text { popular }\end{array}$ & Guru tahfidz \\
\hline $14.00-15.00$ & Berkumpul sesuai kelas & Guru tahfidz \\
\hline $15.00-16.00$ & Setor hafalan dan pulang & Guru tahfidz \\
\hline
\end{tabular}

Tahapan-tahapan dalam perencanaan program hafalan Al-Qur'an yang ada di SMP Islam Mbah Bolong Jombang ini sangatlah berkaitan jika dihubungkan dengan teori langkah-langkah penyusunan program yang dirumuskan oleh Muhaimin dalam bukunya yang berjudul Manajemen Pendidikan Aplikasi dalam Penyusunan Program di Sekolah.

Adapun rumusan dari Muhaimin dalam menyusun program ada empat langkah yang harus dilaksanakan, yaitu menetapkan program, menentukan indikator keberhasilan atau tujuan manfaat dari suatu program, dan menetapkan penanggungjawab program. ${ }^{20}$

Tahapan awal dalam menyusun suatu program yaitu sebaiknya menetapkan program yang akan dilakukan. Hal ini tentu dengan landasan dan latar belakang yang tepat agar program yang dilaksanakan sesuai dengan kebutuhan sekolah. ${ }^{21}$ Penetapan program hafalan Al-Qur'an di SMP Islam Mbah Bolong Jombang ini disesuaikan dengan visi-misi sekolah tidak serta merta menetapkan program hafalan Al-Qur'an tanpa adanya acuan atau tujuan yang akan dicapai.

${ }^{20}$ Muhaimin, dkk, Manajemen Pendidikan: Aplikasi dalam Penyusunan Rencana Pengembangan Sekolah (Jakarta: Kencana 2009), 200

${ }^{21}$ Ibid..200 
Program yang ada pastinya punya manfaat dan tujuan dan manfaat tersebut akan berdampak pada sumber daya manusia yang ada didalamnya yang meliputi: guru, peserta didik, bahkan bisa juga orang tua.

Penanggungjawab terhadap program hafalan yang akan dilaksanakan merupakan suatu hal yang harus diperhatikan dengan sebaik-baiknya karena dalam menentukan penanggungjawab tentu harus dengan pertimbangan dan juga disesuaikan dengan bidang masingmasing. Dan tahapan yang terakhir adalah menyusun kegiatan dan jadwal kegiatan dari program yang dilaksanakan sehingga nantinya program tersebut bisa berjalan dengan efektif dan efisien serta terarah.

\section{Pelaksanaan Program Hafalan Al-Qur'an}

Pelaksanaan kegiatan program hafalan Al-Qur'an di SMP Islam Mbah Bolong masih belum memiliki RPP yang mendetail mengenai kegiatan program hafalan Al-Qur'an. Dalam menyusun pelaksanaan implementsi program tahfidzul Qur'an guru tahfidz hanya mencantumkan bagaimana nanti proses setoran dan pengulangan juga proses penilaian guru tahfidz terhadap perolehan hafalan setiap peserta didik di SMP Islam Mbah Bolong Jombang.

Implementasi program hafalan Al-Qur'an di SMP Islam Mbah Bolong ini dengan membagi setiap kelas untuk menghafal surat-surat yang telah dicapai oleh peserta didik. 1 ayat untuk setiap harinya, dapat lebih dari 1 ayat yang ditentukan itu juga diperbolehkan. Pembiasaanpembiasaan untuk mendukung kegiatan muatan lokal yang ada di sekolah memang haruslah dilaksanakan, seperti yang dikatakan oleh salah satu pengajar tahfidz di SMP Islam Mabh Bolong Jombang ini meliputi pembiasaan membaca Al-Qur'an bersama-sama sebelum memulai kegiatan belajar mengajar.

Pembiasaan sebelum melakukan kegiatan belajar mengajar dengan dipimpin langsung oleh kepala sekolah yang dilaksanakan dalam ruangan atau kadang di musholla. Kemudian masuk ke dalam kelas yang langsung dibimbing oleh guru masing-masing dengan membaca surat-surat pendek dan do'a sebelum melakukan pembelajaran. Proses pelaksanaan meliputi kegiataan membuka, kegiatan inti kemudian kegiatan penutup pembelajaran.

\section{Evaluasi atau penilaian Program Hafalan Al-Quran}

Penilaian dalam pembelajaran tahfidz diukur melalui tes lisan berupa setoran hafalan. Setiap hari peserta didik atau siswa harus menyetorkan 1 ayat yang sudah ditentukan oleh guru atau ustadz program hafalan Al-Qur'an sesuai apa yang dicapai oleh peserta didik. 
Penilaian ini juga diukur dengan memperhatikan bacaan AlQur'annya seperti makborijul buruf yang diucapkan, tajwid yang dilantunkan sudah sesuai atau belum dengan bacaannya, dan kelancaran dalam membaca setiap 1 ayat yang telah diperintahkan atau telah ditentukan.

Penilaian hafalan Al-Qur'an di SMP Islam Mbah Bolong ini menggunakan sistem buku dimana buku tersebut telah diberi kolom dengan cover buku meliputi biodata setiap siswa seperti: nama, kelas, alamat dan isi buku telah tercantum pula kolom-kolom yang telah dilengkapi dengan nomor urut, surat yang dihafal, ayat-ayat yang dihafal, shohih (sebagai penilaian bahwa siswa dapat menghafal dan lulus), Khoto' (sebagai penilai bahwa siswa belum dapat menghafal dan harus mengulang), tanda tangan guru pengajar atau ustadz-ustadzah yang mengajar, dan tanda tangan orangtua untuk memantau.

Hal tersebut memang belumlah dikatakan sempurna sesuai dengan teori-teori yang ada namun sudah ada feedback dengan adanya catatan penilaian untuk setor hafalan bisa mengetahui progres dari hafalan peserta didik tersebut. Evaluasi berasal dari Bahasa Inggris yaitu evaluation. Menurut Mehrens dan lehman yang dikutip oleh Ngalim Purwanto, evaluasi adalah suatu proses perencanaan, memproleh dan menyediakan informasi yang sangat diperlukan untuk alternatif-alternatif keputusan. ${ }^{22}$

\section{Penutup}

Berdasarkan hasil penelitian yang berjudul "Implementasi Program Hafalan Al-Qur'an di SMP Islam Mbah Bolong Jombang", maka dapat diambil kesimpulan antara lain: 1) Perencanaan Program Hafalan AlQuran yang ada di SMP Islam Mbah Bolong Jombang harus melalui musyawarah antara pendiri, pimpinan sekolah kemudian perwakilan dari lembaga yang bekerjasama dalam menentukan muatan lokal di SMP Islam Mbah Bolong dan terapat beberapa langkah dalam merencanakan program hafalan Al-Qur'an di SMP Islam Mbah Bolong Jombang yaitu: Penetapan Program, Tujuan dan manfaat program, Menentukan Penanggung jawab program, dan penetapan aloksi waktu. 2) Pelaksanaan Program Hafalan Al-Quran dimulai dengan tahap pertama, Guru membuka kegiatan pembelajaran sekitar 15 menit dengan membaca bacaan Fatihah kemudian disusul dengan membaca surat-surat pendek maupun do'a-do'a secara bersamaan dan serentak yang dibimbing langsung dengan gguru yang ada di depan siswa. Tahap kedua, guru

${ }_{22}^{2}$ M. Ngalim Purwanto, M.P. Prinsip-prinsip dan Teknik Evaluasi Pengajaran, (Bandung: PT Remaja Rosdakarya, 2004), Cet ke 12, 3 
memulai dengan membuka Al-Qur'an dan menunjukkan ayat yang akan dibaca kemudian guru membaca terlebih dahulu ayat dengan tajwid dan makhroj yang benar dan fashih, kemudian peserta didik menirukan sesuai apa yang telah dibacakan guru didepan, kemudian jika sudah mencapai 1 ayat peserta didik diwajibkan untuk menyetorkannya ke guru bimbingannya. Tahap ketiga, tahap ini mengulang kembali bacaan yang telah dibaca dan disetorkan kepada guru pengajar kemudian guru pembimbing untuk membaca do'a setelah membaca Al-Qur'an. 3) Penilaian Program Hafalan Al-Qur'an yaitu dengan menggunakan buku prestasi siswa ketika sudah menyetor hafalan kepada ustadz atua ustadzah sejauhmana kemampuan atau prestasi peserta didik dalam hafalan Al-Qur'an. Dalam buku penilaian tersusun identitas siswa kemudian kolom untuk penilaian dilengkapi dengan tanda tangan ustadz /ustadzah dan tandatangan orangtua. 


\section{Daftar Pustaka}

Abdul Fattah Az-zawawi, Yahya. Revolusi Menghafal Al-Qur'an, Surakarta: Insan Kamil, 2013.

An-Nawawi, Imam. Adab dan Tata Cara Menjaga Al-Qur'an, Jakarta: Pustaka Amani, 2001

Arikunto, Suharsimi dan Ceci safrudin, Evaluasi Program Pendidikan Pedoman Teoritis Praktis bagi Mahasiswa dan Praktisi Pendidikan. Jakarta: Bumi Aksara, 2010) cet ke-2

Abdul Karim Al-Lahim, Khalid bin. Metode Mtakhir Cara Cepat Menghafal Bandung: Rosdakarya, 2011

Indrawan W.S. Kamus Lengkap Bahasa Indonesia, Jombang: Lintas Media, 2000.

Kementrian Agama Provinsi DKI Jakarta, Kurikulum Muatan Lokal HAfalan Al-Qur'an Madrasah Tsanawiyah, DKI Jakarta, 2013

Lutfi, Ahmad. Pembelajaran Al-Qur'an dan Hadits. Jakarta: Direktorat Pendidikan Islam, 2009

Muhaimin, dkk, Manajemen Pendidikan: Aplikasi dalam Penyusunan Rencana Pengembangan Sekolah. Jakarta: Kencana 2009

Munawwir, A.W. Kamus Al-Munawnir Arab - Indonesia, Surabaya: Pustaka Progressif, 1997 Cet ke 14,

Nana. Sudjana. Dasar-dasar Proses Belajar Mengajar. Bandung: Sinar Baru, 2009.

Prastowo, Andi. Metode Penenlitian Kualitatif dalam Perspektif Rancangan Penelitian, Jogjakarta, Ar-Ruzz Media, 2011.

Wiwi, Cara Cepat Bisa Menghafal Al-Qur'an, Yogjakarta: Kencana Media, 2008.

W.J.S Poerdarminta, Kamus umum Bahasa Indonesia, Jakarta: Balai Pustaka, 1982.

Usman Husaini dan Purnama Setiadi Akbar, Metodologi Penelitian Sosial, Jakarta: Bumi Aksara, 2009.

Hasil wawancara dengan admin SMP Islam Mbah Bolong Jombang, pada tanggal 5 Juli 2020. 
Khoirun Nisa' \& Chusnul Chotimah 